\title{
Laparoscopic cholecystectomy in obese patients
}

\author{
Ahmed Tariq Hamed ${ }^{\star}$, Muzahm Al-khyatt**, Hisham A.Al-Atrakchi ${ }^{\star \star *}$ \\ * Department of Surgery, Al-Jumhory Teaching Hospital, Mosul ;** Chairman of Ninevah University, Mosul; \\ ${ }^{\star \star \star \star}$ Department of Surgery, College of Medicine, University of Mosul, Mosul, Iraq. \\ Correspondence: Ahmed Tariq Hamed. aths72@yahoo.com.
}

(Ann Coll Med Mosul 2018; 40 (2): 54-58).

Received:15 $5^{\text {th }}$ April 1018 , accepted $2^{\text {nd }}$ Dec. 2018.

\section{ABSTRACT}

Background: Obesity has been considered as a relative contraindication to laparoscopic cholecystectomy. Aim: Evaluating the safety of laparoscopic cholecystectomy in obese patients.

Patients and methods: The study was performed in Al-Jomhoory Teaching Hospital, Mosul City. From July 2004 to January 2015. This is a prospective study included 1145 patients who underwent laparoscopic cholecystectomy. All patients from Mosul province, were divided according to the body mass index into two groups. Group I included 141 patients (12.3\%) who were obese (BMI more than 30), and group II, included 1004 non-obese (87.7\%) (BMI less than 30). Peroperative and Postoperative complications, conversion rate, and hospital stay were compared between these two groups.

Results: There was no difference between obese and non-obese groups in preoperative complications, except Subcutaneous insufflations which occurred in 5 cases $(3.5 \%)$ and bleeding from the portal site in 3 cases $(2.1 \%)$ in obese patients. Regarding to the pre and post operative complications there were no significant difference between the two groups with $p$ value $(p \leq 0.05)$.

Conclusion: Laparoscopic cholecystectomy is a safe and effective treatment for obese patients with cholecystitis. There is no difference in preoperative and postoperative technical procedures between obese and non-obese patients.

Keywords: Cholecystectomy, laparoscopy, obese.

$$
\begin{aligned}
& \text { عمليات رفع المرارة بالمنظار للمرضى المصابين بالسمنة }
\end{aligned}
$$

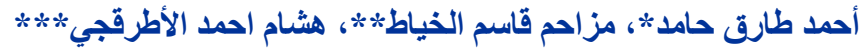

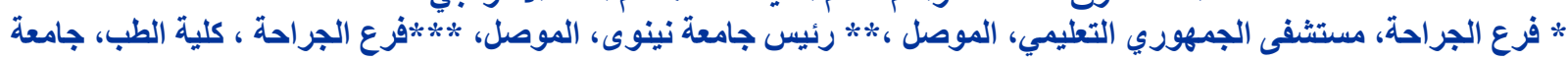

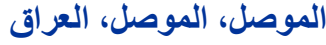

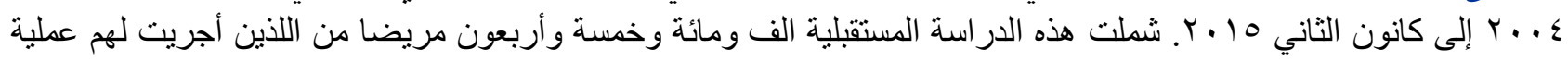

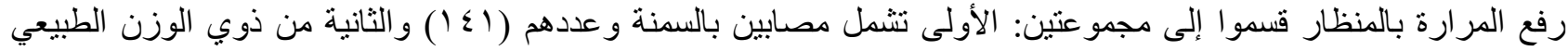

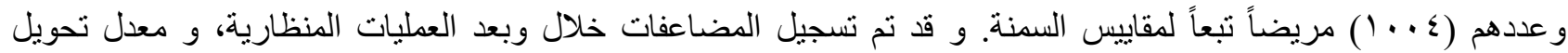

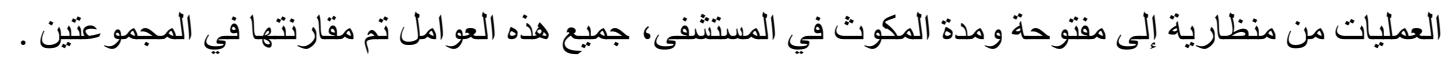

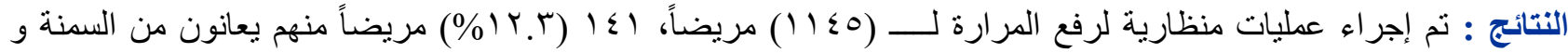

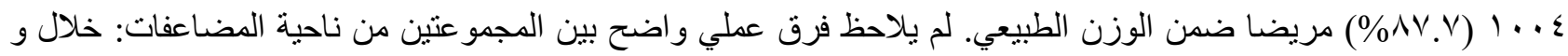
بعد العمليات المنظارية، وتحويل العمليات من منظارية إلى عمليات فتح بطن، و كذللك لا يو جد فرق في مدة المكوث في المستشفى 


$$
\begin{aligned}
& \text { بعد إجر اء العمليات، بإستثناء فرق واحد وهو مدة إجراء العملية حيث لوحظ أن العمليات المنظارية للمرضى الذين يعانون من }
\end{aligned}
$$

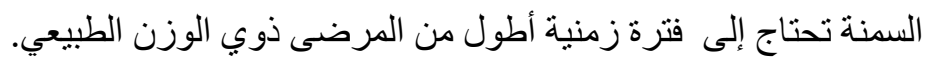

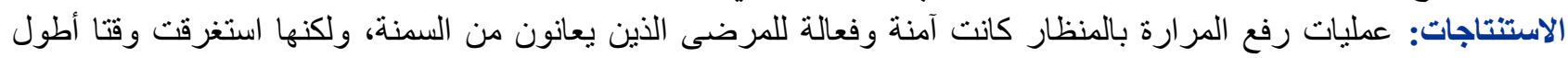

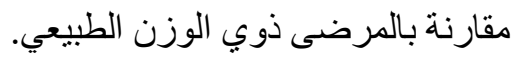

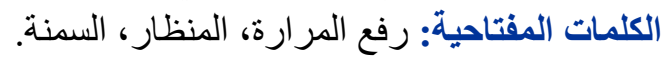

\section{INTRODUCTION}

$\mathrm{M}$ inimal access surgery is a marriage of modern technology and surgical innovation that aims to accomplish surgical therapeutic goal with minimal somatic and psychological trauma. ${ }^{1}$ Laparoscopic cholecystectomy is a minimally invasive procedure in which the gallbladder is removed. ${ }^{2}$ For more than a century, classical cholecystectomy has been the method of choice in the surgical management of gall bladder diseases. At the end of the eighties and the beginning of the nineties of the $20^{\text {th }}$ Century, laparoscopic cholecystectomy (LC) was introduced, gained more and more acceptance, and now appears to have taken over the position of open cholecystectomy for both chronic and acute cholecystitis. ${ }^{2,3,4}$

Laparoscopic surgery has proved to be a safe and effective procedure in the obese population. In fact, some procedures are less difficult than their open counterpart for morbidly obese patients. Technical difficulties occur, however, in obtaining pneumoperitoneum, in reaching the operative region adequately and in achieving adequate exposure in the presence of an obese colon. ${ }^{1}$

Conventional abdominal surgery in the grossly obese is associated with an increased rate of wound infection, atelectasis, respiratory tract infection and deep vein thrombosis (DVT) in postoperative period. ${ }^{5-10}$

Major surgery in obese patients has traditionally been considered to carry increased risk. The laparoscopic technique represents a great advance in cholecystectomy, because the patient is less debilitated by the operation than by open technique. ${ }^{11,12}$ This study aimed to evaluate the safety of laparoscopic cholecystectomy in obese in comparison to non-obese patients with cholecystitis in Mosul province.

\section{PATIENTS AND METHODS}

From July 2004 to January 2015, case control study included 1145 patients with cholecystitis including chronic (932 patients) and acute (213 patients) were submitted to laparoscopic cholecystectomy in Al-Jamhoori Teaching Hospital, Mosul, Iraq.

Clinical assessment, ultrasound, routine preoperative investigations and preoperative evaluation by specialist anesthesiologists were done.

We classified all patients into two groups according to the body mass index, group I obese included patient with BMI more than 30 and group II non-obese with BMI less than 30 and comparison was done between the two groups regarding preoperative complications, conversion rate to open cholecystectomy and post-operative complication.

Some patients were excluded preoperatively from this study, these include patients with liver cirrhosis, obstructive jaundice and patients with class III and IV American Society of Anesthesiologist (ASA).

\section{Operative technique}

We applied the American approach regarding the position of the patients and gall bladder retraction. ${ }^{1}$ The patients were placed in supine position with head up 15 degrees, right sided up by 10 degrees, the surgeon stood on the left of the patient, with the zero-degree camera man and other two assistants on the right side. Standard four ports technique was used in all cases, two of them 10 $\mathrm{mm}$, and two $5 \mathrm{~mm}$.

Twelve to fifteen $\mathrm{mm} \mathrm{Hg}$ insufflations (pneumoperitoneum) were created using either closed technique by Veress needle, or open method (Hasson's technique) ${ }^{1}$, intra-abdominal pressure did not exceed $15 \mathrm{~mm}$. Hg.

Ten millimeters port was put in the sub-umbilical region for insertion of the video laparoscope. The other 3 ports were inserted under vision; a $10 \mathrm{~mm}$ port is placed in the epigastric region. Five millimeters port was placed on the anterior axillary 
line, $10 \mathrm{~cm}$ distance below the right costal margin. The other $5 \mathrm{~mm}$, port was inserted in midclavicular line about $4 \mathrm{~cm}$. below right costal margin. Calot's triangle was dissected by using mono-polar hook device near the junctions of the gall bladder and cystic duct to expose the cystic duct and identify the cystic artery. The cystic artery was clipped using titanium clips. The cystic duct was clipped using titanium clips, then dissection of gall bladder was completed. After that the gall bladder was delivered through the epigastric port. The instruments were then removed under vision, and deflation of pneumoperitoneum was done to reduce postoperative abdominal pain. The fascia of umbilical port closed using absorbable suture (Vicryl 2/0) and the skin of $10 \mathrm{~mm}$ port closed by one stitch, with non-absorbable suture.

Postoperative care included pain relief by Diclofenac injection (75 mg IM twice daily), and completion of the course of antibiotic in acute cholecystitis. Intra-venous fluid was stopped when the bowel sounds became normal. Patients were encouraged to walk as early as possible with hospital stay interval 12-24 hours. Postoperative follow up was done for about (4) months. SPSS software was used to analysis of the result. ANOVA was used and $P$ value less than 0.05 considered significant.

\section{RESULT}

Sex and Age distribution of the patients, there were 141 patients (12.3\%) in group I: 42 males and 99 females, 1004 patients (87.7\%) in group II: 120 males and 884 females. (Table 1)

I. Per-operative difficulties and complications: (Table 2)

1. $\mathrm{Co}_{2}$ insufflation:

Subcutaneous insufflation occurred in 5 cases (3.5\%) in group I, but it did not occur in group II.

2. Port site bleeding and hematoma:

Three cases $(2.1 \%)$ in group I, but did not occur in group II.

3. Gall bladder perforation and stone spillage:

It occurred in 5 cases (3.5\%) in group I with bile and stones leakage, and 30 cases $(2.9 \%)$ in group

II, with bile and stone leakage.

II. Post-operative complications: (Table 3)

1. Wound infection:

Wound infection of umbilical port occurred in 2 cases (1.4\%) in group I and 26 cases $(2.5 \%)$ in group II.

2. Port hernia:

Umbilical port hernia occurred in 6 cases (4.2\%) in group I (6 months postoperatively) but did not occur in group II.

3. Shoulder pain:

47 cases $(33.3 \%)$ in group I, whereas 310 cases $(30.8 \%)$ in group II suffered from right shoulder pain post-operatively.

III. Conversion rate: (Table 3)

The main cause of conversion occurred due to either dense adhesion or inability to define Calot's triangle. 4 cases (2.8\%) in group I, 21 (2\%) cases in group II.

Table 1. Sex and Age distribution of the patients.

\begin{tabular}{|c|c|c|c|c|c|c|c|c|}
\hline \multirow{2}{*}{$\begin{array}{l}\text { Age } \\
\text { group }\end{array}$} & \multicolumn{4}{|c|}{ Group I } & \multicolumn{4}{|c|}{ Group II } \\
\hline & $\begin{array}{c}\text { No. of } \\
\text { females }\end{array}$ & $\%$ & $\begin{array}{l}\text { No. of } \\
\text { males }\end{array}$ & $\%$ & $\begin{array}{c}\text { No. of } \\
\text { females }\end{array}$ & $\%$ & $\begin{array}{l}\text { No. of } \\
\text { males }\end{array}$ & $\%$ \\
\hline $10-20$ & 2 & 2 & - & - & 42 & 4.8 & 2 & 1.7 \\
\hline $21-30$ & 10 & 10.1 & 5 & 11.9 & 95 & 10.7 & 10 & 8.3 \\
\hline $31-40$ & 29 & 29.3 & 8 & 19 & 209 & 23.6 & 41 & 34.2 \\
\hline $41-50$ & 40 & 40.4 & 18 & 42.9 & 362 & 41 & 31 & 25.8 \\
\hline $51-60$ & 13 & 13.1 & 10 & 23.8 & 126 & 14.2 & 26 & 21.7 \\
\hline $61-70$ & 5 & 5.1 & 1 & 2.4 & 50 & 5.7 & 10 & 8.3 \\
\hline Total & 99 & $100 \%$ & 42 & $100 \%$ & 884 & $100 \%$ & 120 & $100 \%$ \\
\hline
\end{tabular}


Table 2. Per-operative difficulties and complications.

\begin{tabular}{lcccc}
\hline $\begin{array}{l}\text { Per-operative } \\
\text { difficulties and } \\
\text { complications }\end{array}$ & \multicolumn{2}{c}{ Group I } & \multicolumn{2}{c}{ Group II } \\
\cline { 2 - 5 } $\mathrm{Co}_{2}$ insufflation & No. & $\%$ & No. & $\%$ \\
$\begin{array}{l}\text { Port site Bleeding and } \\
\text { hematoma }\end{array}$ & 5 & $3.5 \%$ & - & - \\
$\begin{array}{l}\text { Gall bladder perforation } \\
\text { and stone spillage }\end{array}$ & 5 & $3.5 \%$ & 30 & $2.9 \%$ \\
\hline
\end{tabular}

Table 3. Post-operative complication and Conversion rate.

\begin{tabular}{lcccc}
\hline \multirow{2}{*}{$\begin{array}{l}\text { Post-operative } \\
\text { complication }\end{array}$} & \multicolumn{2}{c}{ Group I } & \multicolumn{3}{c}{ Group II } \\
\cline { 2 - 5 } Wound infection & No. & $\%$ & No. & $\%$ \\
\hline Port hernia & 2 & $1.4 \%$ & 26 & $2.5 \%$ \\
\hline Shoulder pain & 6 & $4.2 \%$ & - & - \\
\hline Conversion rate & 47 & $33.3 \%$ & 310 & $30 \%$ \\
\hline
\end{tabular}

Regarding to the pre and post-operative complications there were no significant difference between the two groups with $p$ value $(p \leq 0.05)$.

\section{DISCUSSION}

In this work, subcutaneous insufflation using Veress needle occurred in 5 cases (3.5\%) in group I, due to excessive subcutaneous fat, is agreement with Gatsoulis et al. ${ }^{11}$ Any surgeon experienced with a laparoscopic approach to intra-abdominal surgery on obese patients is aware of the associated increased difficulty. The increased thickness of the abdominal wall makes the establishment of the pneumoperitoneum and trocar introduction more difficult.

In this study, the peroperative complications of the two groups were similar, except the preoperative port site bleeding which was minor in group I, 3 cases (2.1\%). This can related to excessive subcutaneous fat in obese patients there is diminished ability to trans-illuminate the abdominal wall to avoid injury to the superficial abdominal wall vessels when placing trocars in obese patients. ${ }^{12,13}$ Stopping the bleeding from the port sites can be problematic because of the small size of the incision, and the fact that these bleeding points are situated deep in the incision. This is especially true in obese patients. In these circumstances, control of bleeding requires either enlargement of the incision or placement of deep sutures. ${ }^{14}$

Perforation of (GB) is reported to be up to $30 \%$ by some authors, ${ }^{1}$ which is higher than our results $(3.5 \%)$ in group I, and (2.9\%) in group II, and considered by some to be expected (in acute cholecystitis) and not a complication. ${ }^{15}$ If perforation occurs, extensive prompt retrieval of the bile and stones spillage must be done along with abundant irrigation. In case of inadequate aspiration and irrigation, the patient must be closely followed. ${ }^{16}$

In this study, there is no significant difference in postoperative complications, which is in agreement with the recent reports of LC. in obese and nonobese patients that showed no significant difference in complications rate. ${ }^{11,13,17,18}$

In this work, there was no difference in the conversion rate between obese group which was $(2.8 \%)$, and non-obese group (2\%), which is in agreement with many reports that showed no significant difference in the conversion rate between obese and non-obese patients. ${ }^{11,18,19}$ In grossly obese patients the conversion rate ranging from $1.1 \%$ to $11.4 \%$ depending on surgical experience and the inclusion of gall bladder complications. ${ }^{18,19,20}$

\section{CONCLUSION}

In conclusion, laparoscopic cholecystectomy shows no clear difference between obese and nonobese patients in terms of preoperative complications, conversion rate and postoperative complications .

\section{REFERENCES}

1.Darz A. Principles of laparoscopic surgery. In; Russet RCG, Williams NS, Buistrode CJK. Bailey and Love short Practice of surgery , London; Arnold publisher company. 2013, $26^{\text {th }}$ edition, 1(9):93-107.

2.Gadacz TR. Update on Laparoscopic Cholcystectomy. Surg Clin North Am 2000 Aug; 80 (4): 1127-49.

3.Siperstein A.E. General techniques in abdominal laparoscopic surgery. In Carter S.D., Russell RCG, Pitt H.A., Dudley H. Atlas of General surgery $3^{\text {rd }}$ edition, London; Chapman \& Hall Medical 1996; 317-324.

4.AL-Khyatt MK, AL-Atrakchi H.A, AL-Saffar S.I, Monopolar. Diathermy coagulation as an alternativc to clips for cystic artery occlusion in laparoscopic cholecystectomy: A new and safe technique. Ann. Coll. Med. Mosul 2003; 29(2): 71-76.

5.Tiong L, Oh J. Safety and efficacy of a laparoscopic cholecystectomy in the morbid and super obese patients. HPB (Oxford). 2015 Jul; 17(7): 600-604. 
6.Khan MA, Grinberg R, Johnson S, Afthinos JN, Gibbs KE. Laparoscopic Cholecystectomy in the Super Morbidly Obese Patients. Society of American Gastrointestinal and Endoscopic Surgeons. 2012 jan; [Poster]:P481.

7.Sawyer RG, Pruett TL. Wound infection.Surg Clin N Am1994;74:519-536.

8.Ammori BJ, Vezakis A, Davides D. laparoscopic cholecystectomy in morbidly obese patients. Surg Endosc 2001 Nov; 15(11): 1336-9.

9.Sperlongano $\mathrm{P}$, Pisaniello $\mathrm{D}$, Parmeggiani $\mathrm{D}$. laparoscopic cholecystectomy in morbidly obese. Chir Ital 2002 May-Jun; 54(3): 363-6.

10.Kanyari Z, Kincses Z, Juhasz. Complications of laparoscopic cholecystectomy. Magy Seb 2001 Apr; 54(2): 80-3.

11.Gatsoulis N, Koulas S, Kiparos G, Tzafestas N, Pangratis K, Pandis K, Mavrakis G. Laparoscopic cholecystectomy in obese and non obese patients.Obesity Surg 1999;9:459-61.

12.Simopoulos C, Polychronidis A, Botaitis S. Laparoscopic cholecystectomy in morbidly obese patients. Obes Surg 2005 Feb; 15(2):243-6.

13.Tuveri M, Borsezio V, Calo PG, Medas F, Tuveri A, Nicolosi A. Laparoscopic cholecystectomy in the obese: results with the traditional and fundus-first technique. $J$ Laparoendosc Adv Surg Tech A. 2009;19:735-740.
14.Rastogi V, Dy V. Control of port site bleeding from smaller incisions after laparoscopic cholecystectomy surgery: A new, innovative and easier technique. Surg Laparoscop Endosc Percutan Tech 2002 Aug; 12(4): 224-6.

15.Thomsen CO, Bording C, Rasmussen SJR. Day case laparoscopic cholecystectomy in a centre with more than 10 years experience in ambulatory surgery: indications, complications, length of stay, and readmissions. Ambul Surg. 2011;17:37-42.

16.Aytac B, Cakar S. The outcome of gallbladder perforation during laparoscopic cholecystectomy. Acta Chir Belg. 2003 / 103 (4): 388 -91.

17.Champult G,Colon A, Rizk N, Benoit J. Laparoscopic cholecystectomy in 110 cases.Chirurg 1996;121:15-8.

18.Phillips EH, Carroll BJ, Fallas MJ, Pearlstein AR. Comparison of laparoscopic cholecystectomy in obese and non obese patients. Am Surg 1994;60:316-21.

19.Nies C, Bartsch D, Rothmund M. Laparoscopic cholecystectomy in morbid obesity. Chirurg 1994;65:2932.

20.Rego R.E, De- Campos T, De- Moricz A, Silva R.A, Pacheco - Junior A.M. Cholecystectomy in elderly :early results of open versus laparoscopic approach. RevAssoc- Med- Bras . 2003 Jul -sep ; 49 (3):293-9. 